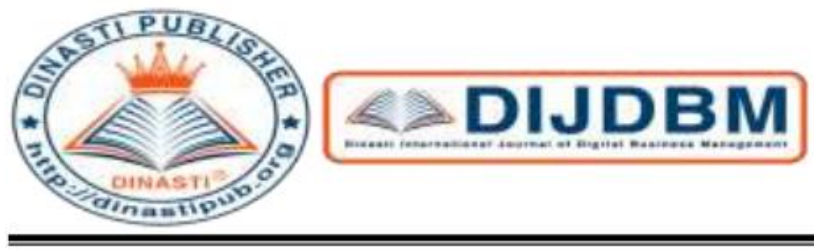

+628138765 4578

+6281387654578

https://dinastipub.org/DIJDBM editor@dinastipub.org

\title{
DETERMINING BUSINESS CONSTRAINTS AMONG INDONESIAN WOMAN ENTREPRENEURS: STUDY FROM LOCAL MSME COMMUNITY
}

\author{
Cut Irna Setiawati ${ }^{1)}$, Zulfaa Putri Nabiilah ${ }^{2)}$ \\ 1,2) Telkom University, Bandung, Indonesia
}

\begin{tabular}{|c|c|}
\hline $\begin{array}{l}\text { ARTICLE INFORMATION } \\
\text { Received: } 18^{\text {th }} \text { March } 2020 \\
\text { Revised: } 19^{\text {th }} \text { April } 2020 \\
\text { Issued: } 30^{\text {th }} \text { April } 2020 \\
\text { Corresponding author: Cut Irna } \\
\text { Setiawati } \\
\text { E-mail: } \\
\text { irnacut@telkomuniversity.ac.id }\end{array}$ & $\begin{array}{l}\text { Abstract: The rapid growth in the number of women } \\
\text { entrepreneurs, isn't equal to the growth of their } \\
\text { businesses which are relatively slower. Same thing that } \\
\text { occur to Benua Citra Niaga MSME community } \\
\text { (BCNc), which have } 66,67 \% \text { women members. Only } \\
30 \% \text { of women entrepreneurs in BCNc who showed } \\
\text { business growth, while other } 70 \% \text { are stagnant. Thus, } \\
\text { this study aims to find out factors that constraining the } \\
\text { business success of women entrepreneurs in BCNc. } \\
\text { This study used a quantitative method. Factor analysis } \\
\text { used for analyzing data. The findings of this study } \\
\text { indicate that there are } 9 \text { dominant factors: lack of } \\
\text { networks to financial institution, underestimated in the } \\
\text { business and family environment, lack of business } \\
\text { education and experience, unfavorable business } \\
\text { regulation, unsupportive economic and political } \\
\text { environment, assets price and taxes problem, work-life } \\
\text { imbalance conflict, limited training and community } \\
\text { access, and hiring unqualified employee. The most } \\
\text { dominant factor is lack of networks to financial } \\
\text { institution. } \\
\text { Keywords: Business Constraints, } \\
\text { Entrepreneurs, Local Community. }\end{array}$ \\
\hline
\end{tabular}

\section{INTRODUCTION}

Entrepreneurs are becoming increasingly interesting professions to be chosen by people of various ages and backgrounds. Everyone can engage in entrepreneurship, regardless of age, race, gender, color, citizenship, or other characteristics, there are no restriction on this form of economic expression (Zimmerer et al., 2008). The high interest in entrepreneurship is evidenced by the number of Micro, Small, and Medium Enterprises (MSME) in Indonesia which is increasing every year. Based on Baand Pusat Statistik (BPS) data from 2015 - 2017, it shows 
that MSME business units in Indonesia increase by 1.000 .000 to 2.000 .000 units annually (www.depkop.go.id, September $25^{\text {th }} 2019$ ).

This large number of MSMEs in Indonesia are inseparable with the participation and role of women entrepreneurs. In the annual publication report of BPS from 2017-2019, Indonesian women show their participation in the growth of business ownership. Every year, there is an increase in the number of women entrepreneurs with an average of 746.000 entrepreneurs (www.bps.go.id, September $25^{\text {th }}$ 2019). The increasing number of women entrepreneurship become a potential asset for Indonesia itself, this women participation in owning a business independently has contributed $9,1 \%$ of Indonesia's Gross Domestic Product (www.katadata.co.id, September $25^{\text {th }} 2019$ ).

Unfortunately, although the data above shows the advancement population of women entrepreneurs every year, this has not been able to compete with a large number of men entrepreneurs. This is proven by BPS publication report about the Condition of Indonesia Labor Force 2017-2019, in the last three years, the population of women entrepreneurs in Indonesia is only about half of the men entrepreneur population (www.bps.go.id, September $25^{\text {th }} 2019$ ). The lower population of women entrepreneurs than their male counterparts, caused by the factors that constraining women entrepreneurs doing entrepreneurial activities. This is in accorandce with Bowen and Hisrich (1986) statement that women entrepreneurs face multidimensional challenges, such as financial problems, credibility, social networks, to the multiple roles in the family (Dhewanto, 2013). All these constraints believed as the barriers that can increase the possibility of women businesses failure and weaken the growth of women entrepreneurs (Dhewanto, 2013).

The various constraints that must be faced by women entrepreneurs, encourage many entrepreneur communities to help women entrepreneurs actively to overcome those things that can restrict them to do entrepreneurial activities. One of entrepreneur communities who can assist their entrepreneur members is Benua Citra Niaga community. Members of Benua Citra Niaga community (BCNc) are dominated by women, there are 66,67\% (178 members) of 267 members of BCNc are women entrepreneurs.

Based on the result of the pre-research survey, $80 \%$ of respondents agreed that personality factor constrained them to get business success, $73,33 \%$ for financial factor, $60 \%$ for womanhood factor and government policy factor, 53,33\% for infrastructural factor, 46,67\% for training and educational factor, also $33,33 \%$ for social factor. This pre-research survey also identified what constraining factor that was considered as the most challenging and the least challenging factor for women entrepreneurs to gain success for their business. The result shows that financial and personality factor are the most challenging factor, whereas the social factor is the least challenging factor that can hinder the to get business success.

Therefore, this study aims to find out and analyze the constraining factors, along with the most dominant factor that limits the success of women entrepreneurs under BCNc. Expectedly, the result of this research can help Benua Citra Niaga community and women entrepreneurs inside to formulate solutions to those existing constraints, so that women entrepreneurs can consider, overcome, and more adaptable the way they achieve business success. 


\section{LITERATURE REVIEW}

Woman entrepreneurship has become an interesting subject for researches to conduct the research about this focus (Teoh and Chong, 2014). This is due to the increasing participation of woman in the last few years to carry out all entrepreneurial activities throughout the world (Panda, 2018; Isaga, 2018; Teoh and Chong, 2014; Jamali, 2009). According to Zimmerer et al. (2008), an increase in the number of women entrepreneurs is because women entrepreneurs have found the best way to be rise by going through various unseen obstacles, that way is to make her own business.

Setiawati and Kartini (2018) stated on their previous research with the title "Understanding The Driver Motivation of Women Entrepreneur in Bandung", factor that motivates women to be an entrepreneur are family oriented, family background and friends, income stability, hobby and facility support, public existency, challenges and risks, and physical limitation.

Based on the research that conducted by Panda (2018) about "Constraints Faced by Women Entrepreneurs in Developing Countries: Review and Ranking", the main constraints faced by women entrepreneurs in developing countries are: gender discrimination, work-family conflict, financial constraints, lack of infrastructural support, unfavorable Business Economic and Political (BEP) environments, lack of entrepreneurship training and education, and personality-based constraints.

While in the previous research entitled "Start-Up Motives and Challenges Facing Female Entrepreneurs in Tanzania" by Isaga (2018), showed that there are 19 constrainging factors that must be faced by wome entrepreneurs in Tanzania. First is, unable to obtain short-term financial capital, unable to obtain long-term financial capital, lack of property rights over assets, good premises and working tools, lack of confidence in women by bank officers, discouragemnet from men when starting/formalizing business/ husband harassment, pressure to offer sexual favors to corrupt government/ private officials, inadequate management cover during maternity leave, lack of business experience, inability to maintain accurate accounting records, unreliable and undependable employees, too much competition, too much government regulation, lack of management training, lack of marketing training, complex/confusing tax structure, complicated business registration process, poor roads /transportation, and electricity problems.

\section{RESEARCH METHODS}

This research was conducted for 5 months from August 2019 until December 2019, in Bandung. The object of this research is Benua Citra Niaga community that has $66,67 \%$ of women entrepreneur members (178 of 267 members). Almost women entrepreneurs in BCNc $(66,23 \%)$ have a culinary business, the rest of them conducted business in fashion, handy craft, services, and others.

This study used a quantitative research method with descriptive-exploratory research. The population of this research was 178 women entrepreneurs as a member of Benua Citra Niaga community. The sampling technique used was non-probability sampling with saturation sampling. Thus, the population, all 178 women entrepreneurs under BCNc used as respondents.

Questionnaires used as a source of primary data. The questionnaires were distributed to 178 women entrepreneurs in Benua Citra Niaga community by messaging application and 
email.While the secondary data obtained from various sources, such as relevant theory books, previous national and international journals, previous theses, also some valid websites.

Factor analysis with the Principle Component Analysis (PCA) method used for analyzing data. This principal component analysis method used to determine the minimum number of factors from the maximum number of variants (Amirullah, 2013). This Figure 1 used as a research framework.

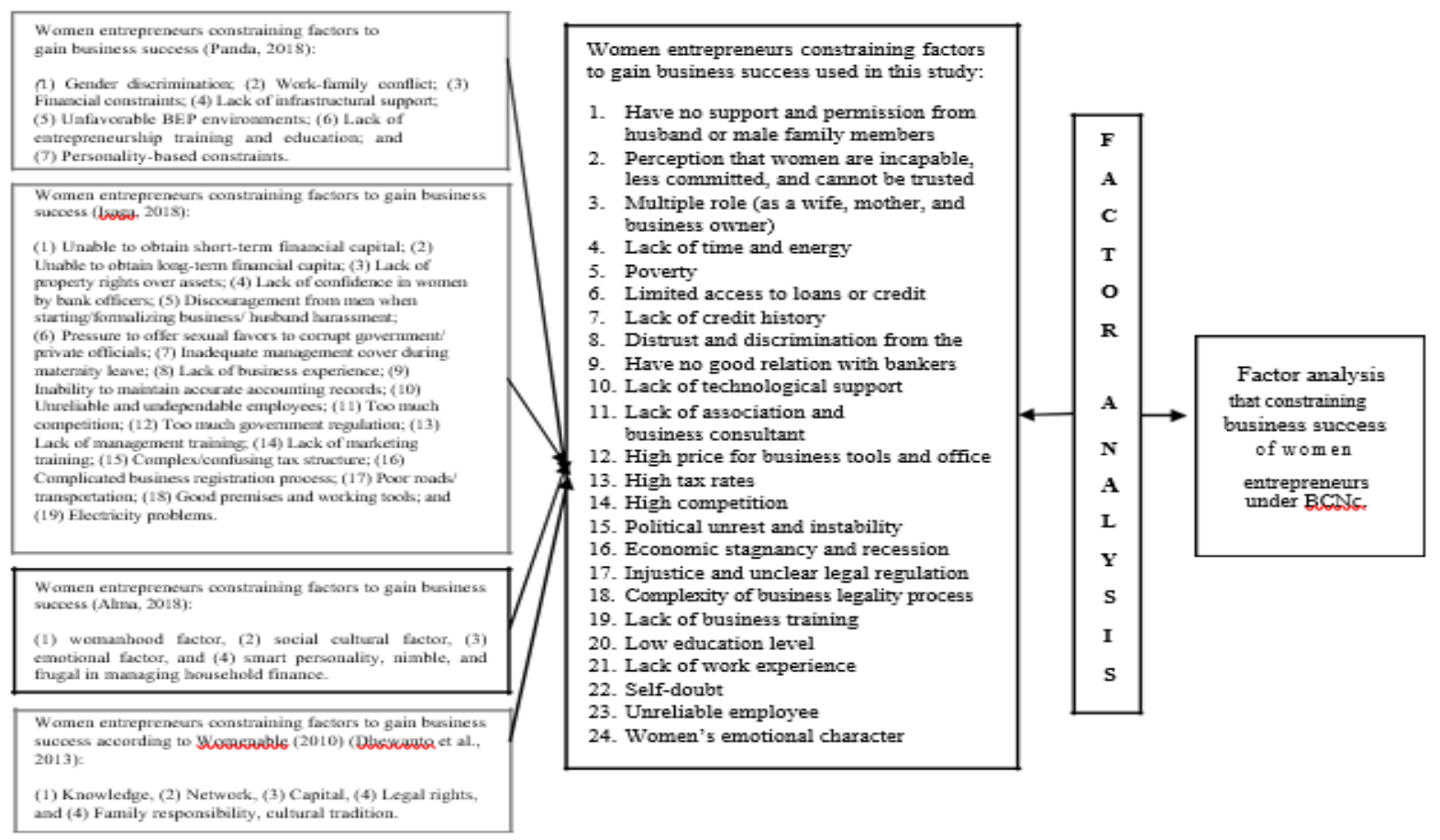

Picture 1. Research framework

\section{FINDINGS AND DISCUSSION KMO and Bartlett's Test}

KMO and Bartlett's used to determine the adequacy of a sample and to find out the correlation among all factors simultaneously. All factors are adequate if the test found KMO value at least 0,5 minimum and the significance value of Bartlett's Test is less than 0,05.

\section{Table 1. KMO and Bartlett's Test}

Kaiser-Meyer-Olkin Measure of Sampling Adequacy.

Bartlett's Test of Approx. Chi-Square

1686.142

Sphericity

df 
Based on Table 1, it can be seen that the KMO value obtained was 0,703 and the significance of Bartlett's Test was 0,000. This result indicated that the result of KMO and Bartlett's Test of this study showed the whole factors were adequate simultaneously. This result due to the KMO value was higher than $0,5(0,703)$, also for the significance was less than 0,05 $(0,000)$.

\section{Anti Image Correlation Test}

Anti image matrics is a matrix that will generate the Measure of Sampling Adequacy (MSA) values. If KMO and Bartlett's test examine simultaneously, anti image correlation test examine partially. Adequate value of anti image correlation test is 0,5 to 1,00 .

Table 2. Anti Image Matrics

\begin{tabular}{lc}
\hline Factors & MSA \\
\hline No moral support from the family & 0,704 \\
No financial support from the family & 0,683 \\
Considered not have enough business knowledge & 0,717 \\
Lack of trust about women's competency from business partner & 0,708 \\
Multiple role (as a wife, mother, and business owner) & 0,556 \\
The demand to have a good time management (for family and business) & 0,534 \\
Lack of energy & 0,560 \\
Have a low capital to run a business & 0,672 \\
Legal restriction for signing loans with own behalf & 0,790 \\
Afraid to apply for a credit & 0,713 \\
Distrust from bankers to approve women's loans & 0,772 \\
Lack of network to bank & 0,712 \\
Assumption that technology is a complex thing & 0,672 \\
Difficulty to join a business community & 0,558 \\
Lack of business consultant & 0,633 \\
High price for quality business assets & 0,769 \\
Complex tax structure & 0,705 \\
Too many competitors & 0,772 \\
Riots which can cause political instability & 0,669 \\
Economic condition is stagnant or tend to decline & 0,709 \\
Unfair business law enforcement & 0,607 \\
Complex legality process & 0,724 \\
Difficult to find business training & 0,786 \\
Low level of formal education & 0,807 \\
Inexperience to work or run a business & 0,763 \\
Lack of confidence with her capability & 0,744 \\
Have employee with poor performance & 0,501 \\
The emotional character of women (prioritizing feeling over logic) & 0,745 \\
\hline
\end{tabular}

All factor items in Table 2 above had MSA values more than 0,5. Thus, further analysis can be done for the whole factors (no factors needed to be eliminated / not included in the subsequent analysis factor).

\section{Communalities Test}


Communalities test's result shows the correlation between the initial factors and the newly formed factors. The extraction method is using the initial value of 1,000 as a benchmark. The greater extraction value, the greater the relationship between an initial factor with the newly formed factor.

\section{Table 3. Communalities Test}

\begin{tabular}{lcc} 
Factors & Initial & Extraction \\
\hline No moral support from the family & 1,000 & 0,629 \\
No financial support from the family & 1,000 & 0,661 \\
Considered not have enough business knowledge & 1,000 & 0,756 \\
Lack of trust about women's competency from business partner & 1,000 & 0,822 \\
Multiple role (as a wife, mother, and business owner) & 1,000 & 0.694 \\
The demand to have a good time management (for family and business) & 1,000 & 0,745 \\
Lack of energy & 1,000 & 0,619 \\
Have a low capital to run a business & 1,000 & 0,591 \\
Legal restriction for signing loans with own behalf & 1,000 & 0,729 \\
Afraid to apply for a credit & 1,000 & 0,584 \\
Distrust from bankers to approve women's loans & 1,000 & 0,723 \\
Lack of network to bank & 1,000 & 0.775 \\
Assumption that technology is a complex thing & 1,000 & 0,555 \\
Difficulty to join a business community & 1,000 & 0,499 \\
Lack of business consultant & 1,000 & 0,609 \\
High price for quality business assets & 1,000 & 0,606 \\
Complex tax structure & 1,000 & 0,519 \\
Too many competitors & 1,000 & 0,618 \\
Riots which can cause political instability & 1,000 & 0,619 \\
Economic condition is stagnant or tend to decline & 1,000 & 0,673 \\
Unfair business law enforcement & 1,000 & 0,601 \\
Complex legality process & 1,000 & 0,724 \\
Difficult to find business training & 1,000 & 0,640 \\
Low level of formal education & 1,000 & 0,576 \\
Inexperience to work or run a business & 1,000 & 0,642 \\
Lack of confidence with her capability & 1,000 & 0,659 \\
Have employee with poor performance & 1,000 & 0,741 \\
The emotional character of women (prioritizing feeling over logic) & 1,000 & 0,619 \\
& & \\
\hline
\end{tabular}

Table 3 shows that the initial factor "Lack of trust about women's "competency from business partner" has the highest communality value $(0,822)$. It means that the "Lack of trust about women's competency from business partner" factor can be explained by the new formed factor by $82,2 \%$ with the strongest correlation with the newly formed factor.

\section{Factoring Process (Total Variance Explained Test)}


The factoring process aims to generate dominant factors that newly formed. The factor analysis study used in this study is the Principle Component Analysis (PCA) which will reduce data to generate new dominant factors. If the result of the test shows an eigenvalue more than 1,00, then the component can be carried out to further analysis. If the result shows eigenvalue less than 1,00, the component can't be included in the model.

Table 4. Total Variance Explained Test

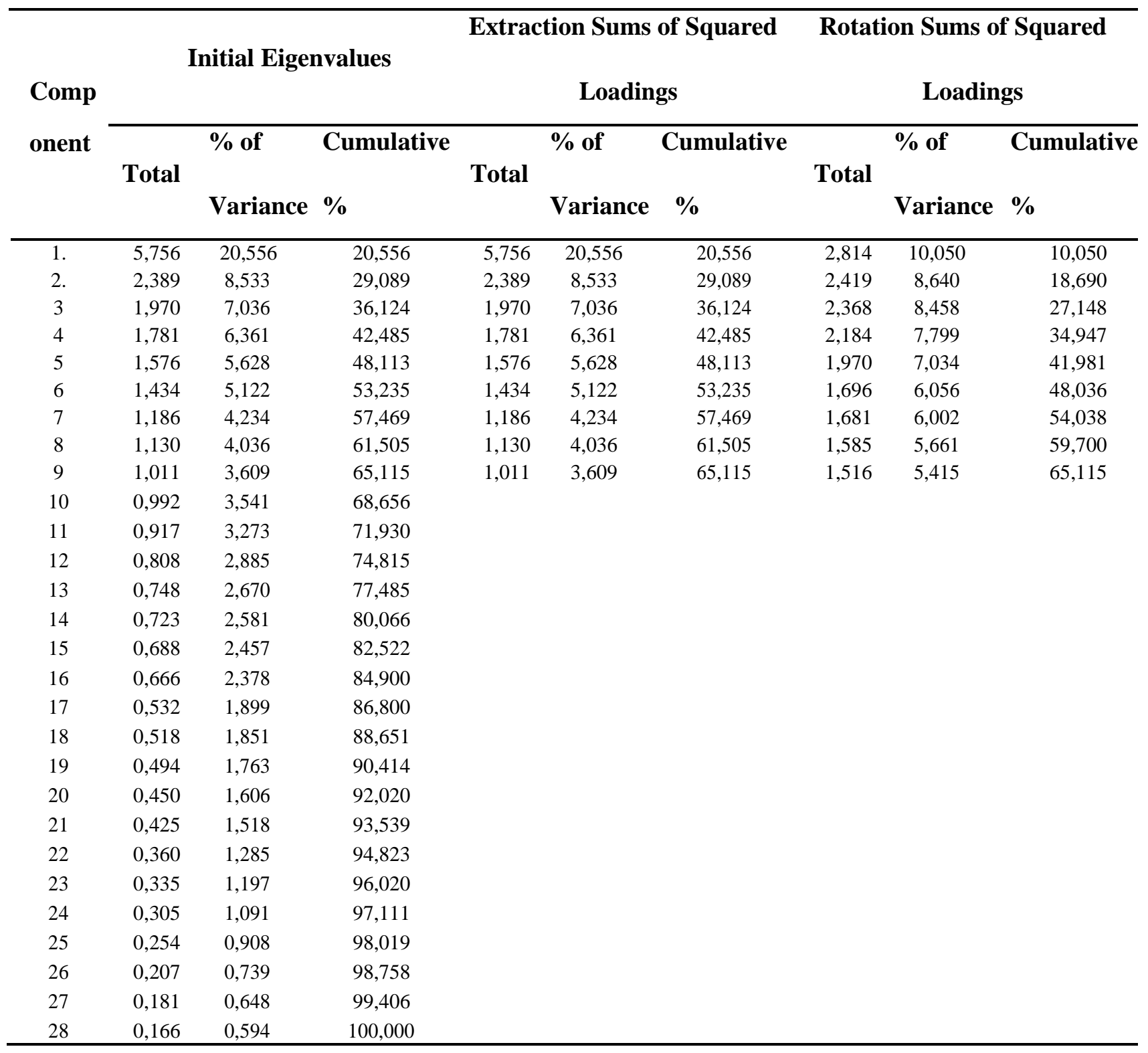

As it shown by Table 4 above, there are only 9 components that have eigenvalue more than 1,00, while 19 other components have eigenvalue less than 1,00. Therefore, there are only 9 newly dominant factors formed. 
There are 28 factors showed by the factor analysis, every factor has a variant equal to 1 . Thus, the total variance generated is $28 \times 1=28$. Then the whole 28 initial factors summarized into 9 new dominant factors. Here are the calculation of every factor's proportion to explain the

whole factor:

$\begin{array}{lll}\text { Component 1 } & : 20,556 / 28 & \text { x 100\% }=73,41 \% \\ \text { Component 2 } & : 8,533 / 28 & \text { x 100\% }=30,47 \% \\ \text { Component 3 } & : 7,036 / 28 & \text { x 100\% }=25,13 \% \\ \text { Component 4 } & : 6,361 / 28 & \text { x 100\% }=22,72 \% \\ \text { Component 5 } & : 5,628 / 28 & \text { x 100\% }=20,10 \% \\ \text { Component 6 } & : 5,122 / 28 & \text { x 100\% }=18,29 \% \\ \text { Component 7 } & : 4,234 / 28 & \text { x 100\% }=15,12 \% \\ \text { Component 8 } & : 4,036 / 28 & \text { x 100\% }=14,41 \% \\ \text { Component 9 } & : 3,609 / 28 & \text { x 100\% }=12,89 \%\end{array}$

From the calculation above, 9 new dominant factors formed will be able to explain $232.54 \%$ of the overall factors.

\section{Factor Grouping Process}

To determine the grouping of constraining factors into the dominant factors formed, need to calculate the correlation between the initial factors in the dominant factor formed. This correlation is shown by the loading factor value. The higher the loading factor of an initial factor generated, the more adequate to be included in the newly formed factor. To generate a more precise loading factor, a varimax rotation factor is used in this study.

Table 5. Rotated Component Matrix

\begin{tabular}{|c|c|c|c|c|c|c|c|c|c|}
\hline \multirow{2}{*}{ Initial Factors } & \multicolumn{9}{|c|}{ Component } \\
\hline & 1 & 2 & 3 & 4 & 5 & 6 & 7 & 8 & 9 \\
\hline No moral support from the family & $-0,057$ & 0,661 & 0,083 & 0,194 & 0,321 & $-0,110$ & 0,167 & $-0,040$ & $-0,001$ \\
\hline No financial support from the family & 0,173 & 0,556 & $-0,027$ & $-0,103$ & 0,453 & $-0,260$ & 0,041 & $-0,104$ & 0,157 \\
\hline $\begin{array}{l}\text { Considered not have enough business } \\
\text { knowledge }\end{array}$ & 0,189 & 0,812 & 0,193 & 0,031 & $-0,065$ & 0,099 & 0,044 & 0,077 & $-0,044$ \\
\hline $\begin{array}{l}\text { Lack of trust about women's competency } \\
\text { from business partner }\end{array}$ & 0,168 & 0,838 & 0,088 & 0,025 & $-0,158$ & 0,195 & 0,057 & 0,109 & 0,076 \\
\hline $\begin{array}{l}\text { Multiple role (as a wife, mother, and } \\
\text { business owner) }\end{array}$ & 0,038 & 0,213 & 0,006 & $-0,021$ & 0,080 & $-0,051$ & 0,740 & 0,222 & 0,203 \\
\hline $\begin{array}{l}\text { The demand to have a good time } \\
\text { management (for family and business) }\end{array}$ & 0,073 & 0,028 & 0,166 & 0,133 & $-0,130$ & 0,115 & 0,800 & $-0,081$ & $-0,130$ \\
\hline Lack of energy & 0,095 & 0,040 & 0,104 & 0,084 & 0,158 & $-0,005$ & 0,409 & $-0,584$ & 0,239 \\
\hline Have a low capital to run a business & 0,199 & 0,066 & 0,067 & 0,043 & 0,594 & 0,213 & 0,277 & $-0,002$ & $-0,255$ \\
\hline $\begin{array}{l}\text { Legal restriction for signing loans with } \\
\text { own behalf }\end{array}$ & 0,793 & 0,108 & 0,049 & $-0,055$ & 0,276 & $-0,021$ & $-0,003$ & 0,077 & 0,024 \\
\hline Afraid to apply for a credit & 0,598 & 0,087 & 0,236 & 0,157 & $-0,068$ & 0,223 & & $-0,065-$ & $81-0$ \\
\hline
\end{tabular}




\begin{tabular}{|c|c|c|c|c|c|c|c|c|c|}
\hline $\begin{array}{l}\text { Distrust from bankers to } \\
\text { approve women's loans }\end{array}$ & 0,790 & 0,171 & 0,132 & 0,122 & 0,135 & 0,091 & 0,050 & 0,049 & 0,077 \\
\hline Lack of network to bank & 0,822 & 0,050 & 0,132 & 0,024 & 0,035 & 0,075 & 0,158 & 0,215 & $-0,029$ \\
\hline $\begin{array}{l}\text { Assumption that technology is a complex } \\
\text { thing }\end{array}$ & $-0,014$ & $-0,070$ & 0,450 & $-0,339$ & 0,292 & 0,323 & 0,177 & $-0,025$ & 0,103 \\
\hline Difficulty to join a business & 0,085 & 0,209 & 0,207 & $-0,019$ & 0,102 & 0,073 & 0,165 & 0,597 & $-0,073$ \\
\hline community Lack of business consultant & 0,032 & 0,037 & 0,063 & 0,287 & 0,083 & 0,541 & $-0,003$ & 0,201 & 0,425 \\
\hline High price for quality business & 0,037 & 0,074 & 0,078 & 0,151 & 0,291 & 0,680 & 0,022 & 0,056 & 0,142 \\
\hline assets Complex tax structure & 0,338 & 0,021 & 0,078 & 0,144 & $-0,036$ & 0,589 & 0,048 & $-0,121$ & $-0,114$ \\
\hline Too many competitors & 0,002 & 0,259 & 0,382 & 0,521 & 0,274 & 0,200 & 0,100 & $-0,049$ & 0,081 \\
\hline Riots which can cause political instability & 0,266 & $-0,063$ & 0,012 & $-0,023$ & 0,666 & 0,084 & $-0,209$ & 0,210 & 0,078 \\
\hline $\begin{array}{l}\text { Economic condition is stagnant or tend to } \\
\text { decline }\end{array}$ & 0,007 & 0,100 & 0,145 & 0,440 & 0,604 & 0,188 & $-0,073$ & $-0,103$ & 0,178 \\
\hline Unfair business law enforcement & 0,001 & $-0,024$ & 0,074 & 0,756 & 0,075 & 0,119 & 0,025 & $-0,044$ & 0,046 \\
\hline Complex legality process & 0,194 & 0,071 & 0,006 & 0,786 & $-0,043$ & 0,124 & 0,098 & 0,118 & 0,152 \\
\hline Difficult to find business training & 0,191 & $-0,097$ & 0,325 & 0,159 & 0,096 & $-0,068$ & 0,126 & 0,619 & 0,224 \\
\hline Low level of formal education & 0,055 & 0,167 & 0,662 & 0,178 & 0,116 & 0,148 & 0,018 & 0,197 & $-0,023$ \\
\hline Inexperience to work or run a business & 0,223 & 0,140 & 0,676 & $-0,017$ & $-0,071$ & 0,110 & $-0,031$ & 0,297 & 0,095 \\
\hline Lack of confidence with her capability & 0,222 & 0,078 & 0,746 & 0,073 & 0,049 & $-0,116$ & 0,150 & $-0,025$ & $-0,050$ \\
\hline Have employee with poor performance & 0,001 & 0,053 & $-0,012$ & 0,108 & 0,053 & 0,051 & 0,032 & $-0,036$ & 0,848 \\
\hline $\begin{array}{l}\text { The emotional character of women } \\
\text { (prioritizing feeling over logic) }\end{array}$ & 0,055 & 0,022 & 0,434 & 0,308 & $-0,136$ & 0,254 & 0,104 & $-0,156$ & 0,463 \\
\hline
\end{tabular}

The results below are based on Table 5, those 28 initial factors can be grouped into 9 new dominant factors as follows:

Dominant factor I $\quad$ : Legal restriction for signing loans with own behalf, afraid to apply for a credit, distrust from bankers to approve women's loans, and lack of network to bank.

Dominant factor II : No moral support from the family, no financial support from the family, considered not have enough business knowledge, and lack of trust about women's competency from business partner.

Dominant factor III : Assumption that technology is a complex thing, low level of formal education, inexperience to work or run a business, and lack ofconfidencewith her capability.

Dominant factor IV : : Too many competitors, unfair business law enforcement, and complex legality process.

Dominant factor $\mathrm{V} \quad$ : Have a low capital to run a business, riots which can cause political instability, and economic condition is stagnant or tend to decline.

Dominant factor VI $\quad$ : Lack of business consultant, high price for quality business assets, and complex tax structure.

Dominant factor VII: Multiple role (as a wife, mother, and business owner) and the demand to have a good time management (for family and business).

Dominant factor VIII : Lack of energy, difficulty to join a business community, and difficult to find business training.

Dominant factor IX $\quad$ Have employee with poor performance and the emotional character of women (prioritizing feeling over logic).

\section{Labelling}

The new formed dominant factors consist of one more components (initial factor that constraining business success of women entrepreneurs). Those 9 dominant factors have not yet 
been named. In this labelling process, every dominant factor is given a name by considering the highest loading factor or considering the relation of all forming components.

Tabel 6. Labelling

\begin{tabular}{llc}
\hline Before Labelling & After Labelling & Variance Value \\
& & (Contribution) \\
\hline Dominant Factor I & Lack of networks to financial institution & $73,41 \%$ \\
Dominant Factor II & Underestimated in the business and family & \\
& environment & $30,47 \%$ \\
Dominant Factor III & Lack of business education and experience & $25,13 \%$ \\
Dominant Factor IV & Unfavorable business regulation & $22,72 \%$ \\
Dominant Factor V & Unsupportive economic and political environmemt & $20,10 \%$ \\
Dominant Factor VI & Assets price and taxes problem & $18,29 \%$ \\
Dominant Factor VII Work-life imbalance conflict Dominant & $15,12 \%$ \\
Factor VIII Limited training and community access & Hiring unqualified employee & $14,41 \%$ \\
Dominant Factor IX & . & $12,89 \%$ \\
\hline
\end{tabular}


According to Table 6, the most dominant factor is "lack of networks to financial institution". This factor was ranked as the first place because women entrepreneurs in BCNc felt hampered with this factor that made them difficult to get capital access from the bank. And then, women entrepreneurs in $\mathrm{BCNc}$ also feel constrained by the underestimated in the business and family environment, they had weak support from external and internal parties around them. Lack of business education and experience are also one of the constraining factors to gain business success for women entrepreneurs in BCNc, this is due to lack of experience and a low level education that causes low self-confidence to manage a business.

Unfavorable business regulation and unsupportive economic and political environment are also constraining factors which come from external environment. These things are certainly out of control, so women entrepreneurs can only accept and make some adjustments to their business. Then, high assets price and taxes problem are also the constraining factors that can hamper the business success of women entrepreneurs in $\mathrm{BCNc}$, because these factors make them spend more capital or costs in managing their business.

As women, they also feel that work-life imbalance conflict is one of the factors that can limit their business success, because they must be able to balance the roles, both in the family and business. Also limited training and community access constrained them to improve their business growth and development. The last one, hiring unqualified employee is also a constraining factor, because of having workers with poor performance, it will hamper the operational process in producing goods or delivering the services.

\section{CONCLUSION AND SUGGESTION}

Based on the analysis of factor that constraining the business success of women entrepreneurs in Benua Citra Niaga community, it can be concluded that there are 9 dominant factors formed: those are: (1) lack of networks to financial institution; (2) underestimated in the business and family environment;(3) lack of business education and experience; (4) unfavorable business regulation; (5) unsupportive economic and political environmemt; (6) assets price and taxes problem; (7) work-life imbalance conflict; (8) limited training and community access; and (9) hiring unqualified employee.

The most dominant factor that formed is lack of networks to financial institution with the contribution of $73,41 \%$ to explain the overall factors. This factor consists of legal restriction for signing loans with own behalf, afraid to apply for credit, distrust from bankers to approve women's loans, and lack of network to the bank.

The result of this research expectedly can be a reference to entrepreneurship insight about women entrepreneurs. The authors try to give some suggestions which can be used for the involved parties. For BCNc, the community can give additional attention to women entrepreneurs like hold a business training specifically for women entrepreneurs and provide woman business consultant, so they can share their advices and experience to overcome those existing constraints. May women entrepreneurs can be more active, persistent, and confident to face every constraint they must overcome, also dare to make a decision which can influence their business growth and development.

For further research, in order to follow up this research, dominant factors generated in this study can be used for regression analysis to find out their influence on other variables that not used in this study, such as business performance or business policy. 


\section{REFERENCE}

Alma, Buchari. 2018. Kewirausahaan untuk Mahasiswa and Umum. CV. Alfabeta:Bandung. Amirullah. 2013. Metodologi Penelitian Manajemen: Disertai Contoh Judul Penelitian and Proposal. Bayumedia Publishing: Malang.

Baand Pusat Statistik. 2016. Keadaan Angkatan Kerja di Indonesia Agustus 2016. [Online] Availabel: www.bps.go.id. [September 25, 2019].

Baand Pusat Statistik. 2017. Keadaan Angkatan Kerja di Indonesia Agustus 2017. [Online] Availabel: www.bps.go.id. [September 25, 2019].

Baand Pusat Statistik. 2018. Keadaan Angkatan Kerja di Indonesia Agustus 2018. [Online] Availabel: www.bps.go.id. [September 25, 2019].

Baand Pusat Statistik. 2019. Keadaan Angkatan Kerja di Indonesia Februari 2019. [Online] Availabel: www.bps.go.id. [September 25, 2019].

Dhewanto, Wawan et al. 2013. Inovasi and Kewirausahaan Sosial Panduan Dasar Menjadi Agen Perubahan. CV. Alfabeta: Bandung.

Griffin, Ricky W. \& Ebert, Ronald J. 2017. Bisnis. ( $8^{\text {th }}$ ed). (Sita Wardhani, Translator). Penerbit Erlangga: Jakarta.

Isaga, Nsubili. 2018. "Start-Up Motives and Challenges Facing Female Entrepreneurs in Tanzania”. International Journal of Gender and Entrepreneurship, Vol. 11(2), pp: 102 - 119.

Jamali,Dima. 2009. "Constrtaints and Opportunities Facing Women Entrepreneurs in Developing Countries”. Gender in Management: An International Journal, Vol. 24(4), pp: $232-251$.

Kementrian Koperasi and UKM. 2017). Perkembangan Data UMKM and Usaha Besar Tahun 2012 - 2017. [Online] Available: www.depkop.go.id. [September 12, 2019].

Kementrian Perindustrian, 2016. Kontribusi UMKM Naik. [Online] Available www.kemenprin.go.id. [September 12, 2019].

Panda, Swati. 2018. "Constraints Faced by Women Entrepreneurs in Developing Countries: Review and Ranking". Gender in Management: An International Journal, Vol. 33(4), pp: $315-331$.

Setiawati, Cut I. \& Kartini, Titin R. 2018. "Understanding The Driver Motivation of Women Entrepreneur in Bandung”. Indonesian Journal of Business and Emtrepreneurship, Vol. 4

(3), pp: $299-307$.

Teoh, Wendy Ming Y. \& Chong, Siong Choy. 2014. "Towards Strengthening the Development of Women Entrepreneurship in Malaysia". Gender in Management: An International Journal, Vol. 29(7), pp: 432-453.

Katadata Publication Team, 2018. Kontribusi Perempuan dalam UMKM Turut Dongkrak $P D B$.

[Online] Available www.katadata.co.id. [September 25, 2019]. 